\title{
Pattern of Genetic Inheritance of Grain Zinc and Iron Content, Agronomic and Biochemical Traits in Bread Wheat Using Mixed Linear Models Under Salinity Stress
}

\section{Hossein Abbasi Holasou}

University of Tabriz Faculty of Agriculture

Seyed Siamak Alavi Kia ( $\sim$ ss.alavikia@gmail.com )

University of Tabriz Faculty of Agriculture

Seyed Abolghasem Mohammadi

University of Tabriz Faculty of Agriculture

Mohammad Moghaddam Vahed

University of Tabriz Faculty of Agriculture

\section{Research Article}

Keywords: Abiotic stress, Genetic control, Grain Zn and Fe content, Zn/Fe efficient uptake, Mixed linear model

Posted Date: April 12th, 2021

DOl: https://doi.org/10.21203/rs.3.rs-367613/v1

License: (c) (1) This work is licensed under a Creative Commons Attribution 4.0 International License.

Read Full License 


\section{Pattern of genetic inheritance of grain zinc and iron content, agronomic and biochemical traits in bread wheat using mixed linear models under salinity stress}

\section{Hossein Abbasi Holasou ${ }^{\mathrm{a}}$, Seyed Siamak Alavi Kia ${ }^{\mathrm{a} *}$, Seyed Abolghasem Mohammadi ${ }^{\mathrm{a}, \mathrm{b}}$, Mohammad Moghaddam Vahed ${ }^{\text {a,b }}$}

${ }^{a}$ Department of Plant Breeding and Biotechnology, Faculty of Agriculture, University of Tabriz, Tabriz, Iran

${ }^{\mathrm{b}}$ Center of Excellence in Cereal Molecular Breeding, University of Tabriz, Tabriz, Iran

*Corresponding author, E-mail: ss.alavikia@gmail.com Tel:+989144172738

Hossein Abbasi Holasou Email: hossein.pdf55@gmail.com ORCID: 0000-0002-5664-007X

Seyed Abolghasem Mohammadi Email: mohammadi@tabrizu.ac.ir ORCID: ORCID: 0000-0001-5518-0094

Mohammad Moghaddam Vahed Email: moghaddamv@yahoo.com 


\begin{abstract}
Wheat is the most important staple food that acts as a primary source of dietary calories, protein and most of the bioavailable micronutrients such as iron $(\mathrm{Fe})$ and zinc $(\mathrm{Zn})$ for the world's population. Understanding genetic control of micronutrients uptake is necessary for development of good quality wheat genotypes. To study the nature of inheritance of $\mathrm{Zn}$ and $\mathrm{Fe}$ efficient uptake under none-saline and saline conditions, two Iranian facultative wheat variety; Navid (salt sensitive, Fe and Zn-deficient) and Roshan (salt tolerant, Fe and Zn-efficient); were crossed to generate six basic generations for generation mean analysis. All the genotypes of these six generations were evaluated for grain $\mathrm{Zn}$ and Fe content, agronomic and biochemical traits under none-saline and saline conditions. For all the studied traits, the non-additive components were greater than the additive component. Additive effects were negative and significant for all traits under non-saline and saline conditions, except for 100-SW in control, MDA in $100 \mathrm{mM}$ salinity level, EL and LeaNaC in all salinity levels. Additive gene actions were important for grain $\mathrm{Zn}$ and $\mathrm{Fe}$ content; while for rest of traits both fixable and non-fixable genetic effects were important. Duplicate dominant type of epistasis was involved in inheritance of all the traits. Broad-sense heritability values ( $>0.6)$ for most traits under non-saline and saline conditions were high, whereas the narrow-sense heritability values for most of the studied traits were low to moderate. These $\mathrm{Zn}$ and Fe efficient uptake indices could be used to select $\mathrm{Zn} / \mathrm{Fe}$ efficient wheat genotypes from segregating populations.
\end{abstract}

Keywords: Abiotic stress, Genetic control, Grain Zn and Fe content, Zn/Fe efficient uptake, Mixed linear model

\title{
Introduction
}

Among the major abiotic stresses, salinity is one of the most adverse environmental factors limiting the growth, survival and production of wheat in Iran and worldwide. Salinity stress generates hyperionic and hyperosmotic stress in wheat, which cause hormonal imbalance, nutrient disturbances and negative impact on yield (Munns and Tester 2008; Daneshbakhsh et al. 213). Iran is a chief producer of wheat in Asia (FAO 2017), challenging for about 34 million ha of salt-affected land area which includes 4.1 million ha of irrigated land (FAO 2000) leading to an annual economic loss of almost US\$ 1 billion (Qadir et al. 2008).

By reducing the micronutrients, the effects of salinity stress can accelerated in cereal crops (Faran et al. 2019). In the other words, high salt concentrations in the soil reduces the root growth leading to poor nutrient uptake, especially $\mathrm{Zn}$ and $\mathrm{Fe}$, due to strong competition between $\mathrm{Zn}$ and $\mathrm{Fe}$ and salt actions which may cause severe 
deficiencies of these elements in the plants (Rehman et al. 2017). Under salt stress, the production of reactive oxygen species (ROS) has increased which causes structural and functional damage on lipids, proteins, nucleic acids and water relations that consequently suppress the photosynthesis, $\mathrm{Zn}$ and $\mathrm{Fe}$ uptake in plants resulting the poor yield (Munns and Tester 2008; Rehman et al. 2017).

To surmount the aforementioned problem and ensure higher crop production, different approaches such as agronomic biofortification (foliar spraying, soil application and/or seed priming) and genetic advancement of crops have been suggested to develop genotypes which can maintain sufficient micronutrients under saline soils (Peleg et al. 2009; Pfeiffer and McClafferty 2007). Among the potential solutions, the breeding of wheat varieties especially landraces and wild relatives of common wheat has been proposed as one of the most cost-effective and environmentally safe approaches to alleviate the malnutrition (Peleg et al. 2009). The agronomic solutions are being exhausted in case of minimizing the impact of salinity stress, and consequent $\mathrm{Zn}$ and Fe deficiency. Therefore, developing salt tolerant genotypes of crops accompanied with higher $\mathrm{Zn}$ and Fe acquisition efficiency would be may be beneficial to minimize micronutrient deficiency gaps in farming communities. Breeding for both tolerance to salt and micronutrients (particularly $\mathrm{Zn}$ and $\mathrm{Fe}$ ) deficiency, in spite of its importance, has even rarely considered in wheat breeding programs.

A primary requirement of such a breeding effort are exploring about genetic variation of component indices of $\mathrm{Zn}$ and $\mathrm{Fe}$ efficiency, including uptake of $\mathrm{Zn}$ and Fe by the roots, translocation, assimilation, and remobilization of them into the grains (Liu et al. 2019). According to Velu et al. (2014), efficient uptake of $\mathrm{Zn}$ and Fe from the soil can be achieved by modifying the morphological and structural traits of root.

Generation means analysis (GMA), a biometrical method developed by Mather and Jinks (1982), is a simple but useful tool for designing breeding strategies to take the advantage of gene interaction existing in succession breeding generations (Mather and Jinks 1982). In GMA, joint scaling test is commonly used to study the inheritance types of traits, in which the gene effects (additive and dominance) and digenic epistatic interactions (additive $\mathrm{x}$ additive; Additive $\mathrm{x}$ dominance; Dominance $\mathrm{x}$ dominance) are set up in a linear model and evaluated by the chi-square test (Mather and Jinks 1982). However, this method has several limitations that can restrict its utilization. This method cannot be used directly for models in which the number of effects is equal or greater than to the number of generation means. On the other hand it is possible that additive, dominance, and epistatic effects are over- or underestimated, since these effects are obtained without error via the least square analysis method (Balestre 
et al. 2012). Additionally, the error terms usually computed based on within-plot variances (Mather and Jinks 1971). In this case, because between-plot variance for the segregating generations is ignored, results may not be very accurate (Piepho and Mohring 2010). Using Mixed linear model developed by Piepho and Mohering (2010), previous issues and problems have been resolved and estimates of genetic effects and generation means as well as all variance components are executed in a single step, while, the traditional method requires two analyses for means and variances, separately.

Genetic control of different traits under abiotic stress conditions has been studied in wheat. Dashti et al. (2010) reported significant additive gene effects and high broad-sense heritability for $\mathrm{K} / \mathrm{Na}$ ratio, $\mathrm{K}^{+}$, and $\mathrm{Na}^{+}$ concluding existence of possibilities to improve these traits under salinity stress condition. Moroni et al. (2013) stated that additive effects were larger than dominant effects for manganese tolerance. Abbasi Holasou et al. (2019) showed that additive, dominance and epistatic effects were involved in the inheritance of agronomic traits under water deficit stress condition. Amiri et al. (2020) reported that both additive and non-additive effects are important for Fe and Zn uptake efficiency at both crosses (Marvdasht $\times$ Rassoul and Marvdasht $\times$ Shahpasand) under normal and drought stress conditions.

To the best of our knowledge, there were no reported records about gene action of zinc and Fe absorption ability under salinity stress conditions in bread wheat. Thus, the main objectives of this study were understanding the types and value of gene effects controlling the inheritance of efficient $\mathrm{Zn}$ and Fe uptake and related characters viz. grain yield, 100-seed weight, shoot dry weight, root dry weight, proline, Malondialdehyde (MDA), Peroxidase (POX), Catalase (CAT) by means of six basic generations $\left(\mathrm{P}_{1}, \mathrm{P}_{2}, \mathrm{~F}_{1}, \mathrm{~F}_{2}, \mathrm{BC}_{1}\right.$, and $\left.\mathrm{BC}_{2}\right)$ of wheat using generation mean analysis according to mixed linear model analysis under salinity stress conditions. Ultimately, this information will be useful for selecting $\mathrm{Zn}$ and Fe-efficient wheat genotypes for cultivation in low- $\mathrm{Zn}$ and Fe soils under salinity stress, thereby providing health benefits to humans.

\section{Materials and Methods}

\section{Plant materials and experiment}

The experiment was conducted under hydroponic greenhouse condition (temperature between $28: 19 \pm 2^{\circ} \mathrm{C}$ day:night on a 16:8-h light:dark photoperiod; humidity between $35-45 \%$; natural light conditions) using a factorial experiment (including two factors; generations and treatments) based on randomized complete block design with three 
replications. The first factor was the six basic generations $\left(\mathrm{P}_{1}, \mathrm{P}_{2}, \mathrm{~F}_{1}, \mathrm{~F}_{2}, \mathrm{BC}_{1}, \mathrm{BC}_{2}\right)$ derived from a cross of two Iranian facultative wheat variety; Navid (salt sensitive, and $\mathrm{Fe}$ and Zn-deficient) and Roshan (salt tolerant, and $\mathrm{Fe}$ and $\mathrm{Zn}$-efficient). The second factor was the levels of $\mathrm{NaCl}$ salinity, including control (no $\mathrm{NaCl}$ ), 100 and $200 \mathrm{mM}$ $\mathrm{NaCl}$. Parents were previously screened for salinity stress, $\mathrm{Zn}$ and Fe efficiency by Khoshgoftarmanesh et al. (2006a and b), Daneshbakhsh et al. (2013) and Sharifi-Soltani et al. (2016).

The seed of generations were planted in 126 plastic pots $(25 \times 25 \mathrm{~cm})$ filled with perlite: vermiculite mixture (4:1 v/v). The 24 plants for each $\mathrm{P}_{1}, \mathrm{P}_{2}, \mathrm{~F}_{1}, \mathrm{BC}_{1}$, and $\mathrm{BC}_{2}$, and 48 plants for $\mathrm{F}_{2}$ were used in each replication. Prior to sowing, qualified seeds of each generation were surface sterilized with $5 \%(\mathrm{~W} / \mathrm{V})$ sodium hypochlorite $(\mathrm{NaClO})$ for 8 min and rinsed well with distilled water several times. To provide uniform seed germination, the seeds were sown on filter paper moistened with deionized water for 7 days in the greenhouse conditions $\left(28 / 20^{\circ} \mathrm{C}\right.$ day/night $\max / \mathrm{min})$. Upon germination, the undamaged seedlings with uniform size and uniform root length were transplanted into pots.

The pots were irrigated using Hoagland solution (Hoagland and Arnon 1950) in 1/4, 1/2 and full ratios on two, four and six days after planting, respectively. The nutrient solutions were changed frequently after every 7 days during the salinity treatment the $\mathrm{pH}$ was adjusted to $6.5 \pm 0.5(\mathrm{EC}=1.3 \mathrm{dsm}-1)$. Salt treatment was applied at 17 days after sowing (DAS), when the third leaf was appeared (Zodaks score (Z) 13; Zodaks et al. 1974). To avoid osmotic shock, salt treatment was imposed stepwise in aliquots of $50 \mathrm{mM}$ in Hoagland's nutrient solution every alternate daily until the appropriate salt treatments were reached. Pots were variedly irrigated from 600 to $650 \mathrm{ml}$ of tap water and saline solutions every alternate period of days to achieve 100\% FC (field capacity) according to weather conditions and growth stage. Avoiding excess salinity due to adding Hoagland solution, perlite substrate within the pots was washed every 14 days, and non-saline and salinity treatments were reapplied. Recorded ECs were $2.1+$ $0.18,9.2+0.2$ and $17.2+0.74$ for 0,100 and $200 \mathrm{mM} \mathrm{NaCl}$, respectively, which were weekly measured.

\section{Phenotypic evaluation}

Sixteen morpho-physiological traits including grain $\mathrm{Fe}$ and $\mathrm{Zn}$ concentration $(\mathrm{GFeC}$ and $\mathrm{GZnC})$, root length $(\mathrm{cm})$, root fresh weight, root dry weight, leaf $\mathrm{Na}^{+}$concentration $\left(\mathrm{LeaNa}{ }^{+} \mathrm{C}\right)$, leaf $\mathrm{K}^{+}$concentration $\left(\mathrm{LeaK}^{+} \mathrm{C}\right), \mathrm{Na}^{+} / \mathrm{K}^{+}$ concentration ratio $\left(\mathrm{LeaK}^{+} / \mathrm{Na}^{+} \mathrm{C}\right)$, Relative water content (RWC), Electric leakage (EL), weight of 100 grains (100SW), grain yield per plant (g/plant), proline content, Catalase (CAT), Peroxidase (POX) and Malondialdehyde (MDA) were measured after 10 weeks from sowing. The shoots were cut off at the perlite-vermiculite mixtures 
surface, and the roots were separated gently from the perlite-vermiculite mixtures via soaking them in deionized water for $10 \mathrm{~min}$. The remaining perlite-vermiculite mixture adhering to the roots was then washed away.

Electric leakage (EL) was determined by the method of Lutts et al. (1996) using the portable electrical conductivity meter on the third leaf. Relative water content (RWC) was measured according to Barrs and Weatherly (1962). Proline concentration was assessed according to Bates et al. (1973). MDA, POX and CAT were assayed by Heath and Packer (1968), Gueta-Dahan et al. (1997) and Singh et al. (2010), respectively. Concentration of $\mathrm{Na}^{+}$and $\mathrm{K}^{+}$was measured on the second leaf after nine weeks using a flame photometer according to Poustini and Siosemardeh (2004) with minor modification, and Fe and Zn concentration was measured according to Chapman and Pratt (1961) using Atomic Absorption Spectrometer (SpectrAA-220, VARIAN, Australia).

\section{Statistical analysis}

The analysis of variance was done using the PROC GLM procedure of SAS System ver. 9.2 (SAS Institute 2007). Generation mean analysis was performed based on genetic model of Mather and Jinks (1982) using mixed linear model (MLM) proposed by Piepho and Mohering (2010) as follows:

$\mathrm{Y}=\mathrm{m}+\alpha[\mathrm{d}]+\beta[\mathrm{h}]+\alpha 2[\mathrm{i}]+2 \alpha \beta[\mathrm{j}]+\beta 2[\mathrm{l}]$

where $\mathrm{Y}, \mathrm{m}, \mathrm{d}, \mathrm{h}, \mathrm{i}, \mathrm{j}$ and $\mathrm{l}$ are mean of one generation, mean of all generations, sum of additive effects, sum of dominance effects, sum of additive $\times$ additive interaction (complementary), sum of additive $\times$ dominant and sum of dominant $x$ dominant interactions (duplicate), respectively. The $\alpha, \beta, 2 \alpha \beta, \alpha^{2}, \beta^{2}$ are the coefficients for the additive, dominant effects and their interactions in the model, respectively. The data that was significant in the ANOVA, showing significant differences between the parents, $\mathrm{P}_{1}$ and $\mathrm{P}_{2}$, was submitted to the lack of fit test for the additive-dominance model, using the SAS macros for PROC Mixed models, as indicated by Piepho and Mohring (2010). According to Piepho and Mohring (2010), the lack of fit test is equivalent to the Joint Scaling Test of Mather and Jinks (1971). The fitness of additive-dominance model was examined using Wald-type F-test (Piepho and Mohering 2010).

Broad-sense and narrow-sense heritabilities (Wright 1968) as well as degree of dominance (Halluer and Miranda 1988) were estimated using following formula:

$\begin{aligned} h_{B}^{2} & =\frac{\mathrm{V}_{\mathrm{G}}}{\mathrm{V}_{\mathrm{G}}+\mathrm{V}_{\mathrm{E}}} \\ h_{N}^{2} & =\frac{\mathrm{V}_{\mathrm{A}}}{\mathrm{V}_{\mathrm{G}}+\mathrm{V}_{\mathrm{E}}}\end{aligned}$ 


$$
\bar{a}=\sqrt{\frac{2 \mathrm{~V}_{\mathrm{D}}}{\mathrm{v}_{\mathrm{A}}}}
$$

Where $V_{G}, V_{A}, V_{D}$, and $V_{E}$ are genotypic variance, additive variance, dominant variance and environmental variance, respectively.

\section{Results}

\section{ANOVA}

Analysis of variance revealed significant $(\mathrm{p} \leq 0.01)$ effects of salinity and generations for all the traits indicating the presence of sufficient genetic variability for carrying out generation mean analysis and estimating heritability. The salinity $\times$ generations interaction was also significant $(\mathrm{p} \leq 0.05)$ for all the traits except $100-\mathrm{SW}$, proline content, GFeC and GZnC (Table 1). The CV varied from $2.05 \%$ for RWC to $15.35 \%$ for $\mathrm{Na}^{+} / \mathrm{K}^{+}$ratio.

The means and standard errors of the six main generations at three salinity levels $(0,100$ and $200 \mathrm{mM})$ are represented in Table 2. It is worth noting that the mean values for $\mathrm{GFeC}, \mathrm{GZnC}, \mathrm{RWC}, \mathrm{LeaNa}^{+} \mathrm{C}$, $\mathrm{LeaK}^{+} \mathrm{C}$, LeaK ${ }^{+} / \mathrm{Na}^{+} \mathrm{C}, \mathrm{CAT}, \mathrm{POX}, \mathrm{MDA}$ and proline in $\mathrm{F}_{1}$ was close to the average of two parents at all three levels of salinity stress, while the means for 100-SW, GY, RL, RFW and RDW in $\mathrm{F}_{1}$ was greater than that of the two parents (Table 2). These results indicated that heterosis relative to mean parents which may be used to help develop hybrid varieties. Heterosis (over best parent) for grain yield was 43.56\%, 28.13\% and 10.34\% at control, 100 and $200 \mathrm{mM}$ salinity levels, respectively. Salinity stress reduced GFeC, GZnC, 100-SW, GY, RL, RFW, RDW, RWC, LeaK ${ }^{+}$C and $\mathrm{LeaK}^{+} / \mathrm{Na}^{+} \mathrm{C}$ although the decrease at $200 \mathrm{mM}$ was more than $100 \mathrm{mM}$. The value of EL, LeaNa ${ }^{+} \mathrm{C}, \mathrm{CAT}, \mathrm{POX}$, MDA and proline were increased by imposing the salinity treatments in all generations (Table 2).

\section{Gene effects and genetic parameters}

Wald-F test revealed significant digenic epistatic interactions for majority of the traits at different salinity conditions. However, the additive-dominance model explained the genetic basis of GFeC and RL at the two higher salinity regimes (100 and $200 \mathrm{mM}$ ), RFW, RDW, MDA and proline under non-saline condition, RWC, EL and CAT at $100 \mathrm{mM} \mathrm{NaCl}$ and $\mathrm{GZnC}$ and $\mathrm{LeaK}^{+} \mathrm{C}$ at $200 \mathrm{mM} \mathrm{NaCl}$.

Generally, the non-additive effects were greater than the additive effect. Additive effects were negative and significant for all traits at all salinity levels ( $\mathrm{P}_{1}$ had smaller values than $\left.\mathrm{P}_{2}\right)$, except for $100-\mathrm{SW}$ in control, and EL and $\mathrm{LeaNa}^{+} \mathrm{C}$ in all salinity levels. The negative additive effect indicates the inheritance of favorable alleles from $\mathrm{P}_{2}$ 
(Roshan) to the progenies. The same trend was observed for the dominance effect for $\mathrm{RWC}$ and $\mathrm{LeaK} / \mathrm{Na}^{+} \mathrm{C}$ at all salinity levels, for 100-SW and $\mathrm{LeaK}^{+} \mathrm{C}$ under non-saline condition and $100 \mathrm{mM}$ level, for GY, MDA and RFW at $100 \mathrm{mM}$ salinity level, for POX at $200 \mathrm{mM}$ salinity level, and for RDW and proline at 100 and $200 \mathrm{mM}$ salinity levels.

The additive $\times$ additive effects were negative and significant for $\mathrm{LeaK}+\mathrm{Na}^{+} \mathrm{C}$ (at all salinity levels), 100SW (at control and $100 \mathrm{mM} \mathrm{NaCl}$ ), GY (at $100 \mathrm{mM} \mathrm{NaCl}$ ), RFW (at $100 \mathrm{mM} \mathrm{NaCl}$ ), RDW (at $100 \mathrm{mM}$ salinity level), RWC (at non-saline condition), $\mathrm{LeaK}^{+} \mathrm{C}$ (at non-saline and $100 \mathrm{mM}$ salinity levels), POX (at $200 \mathrm{mM}$ salinity level), MDA (at $200 \mathrm{mM}$ salinity level) and proline (at 100 and $200 \mathrm{mM}$ salinity levels), but positive and significant $(\mathrm{p} \leq 0.01)$ for $\mathrm{LeaNa}^{+} \mathrm{C}$ (at all salinity levels), EL (at $200 \mathrm{mM}$ salinity level) and MDA (at $200 \mathrm{mM}$ salinity level). Dominance $\times$ dominance effects were positive and statistically significant for GY (at all salinity levels), $\mathrm{LeaK}^{+} / \mathrm{Na}^{+} \mathrm{C}$ (at all salinity levels), 100-SW (at non-saline and $100 \mathrm{mM}$ salinity level), RFW (at 100 and $200 \mathrm{mM}$ salinity levels), RDW (at 100 and $200 \mathrm{mM}$ salinity levels), RWC (at non-saline and $200 \mathrm{mM}$ salinity level), LeaK ${ }^{+} \mathrm{C}$ (at non-saline and $100 \mathrm{mM}$ salinity levels), POX (at $200 \mathrm{mM}$ salinity level), MDA (at $200 \mathrm{mM}$ salinity level), and proline (at 100 and $200 \mathrm{mM}$ salinity levels), whereas for $\mathrm{LeaNa}^{+} \mathrm{C}$ (at 100 and $200 \mathrm{mM}$ salinity levels), EL (under $200 \mathrm{mM}$ treatment) and POX (under non-saline condition), dominance $\times$ dominance gene effects were negative and significant (Table 3).

Duplicate epistatic (dominance and dominance $\times$ dominance components were in opposite directions) digenic effects were ascertained critical in the inheritance of $\mathrm{LeaK}^{+} / \mathrm{Na}^{+} \mathrm{C}$ (at all salinity levels), $\mathrm{RDW}, \mathrm{LeaNa}{ }^{+} \mathrm{C}$, proline (under 100 and $200 \mathrm{mM}$ salinity levels), 100-SW, LeaK ${ }^{+} \mathrm{C}$ (at non-saline and $100 \mathrm{mM}$ salinity levels), RWC, POX (at non-saline and $200 \mathrm{mM}$ salinity levels), GY, RFW, MDA (at $100 \mathrm{mM}$ salinity level) and EL (at $200 \mathrm{mM}$ salinity level). It was suggested that these traits were governed by complex genetic architecture. Delayed selection until the high level of gene fixation is suggested for improvement in these traits (Table 3).

The estimates of additive, dominance, additive $\times$ dominance covariance, and environmental components of variance, broad-sense and narrow-sense heritabilities and degree of dominance for different traits in control and salinity treatments are presented in Table 4 . The additive variance was greater than dominance under both control and salinity conditions for GFeC, RL, RFW, RDW, $\mathrm{LeaK}^{+} \mathrm{C}, \mathrm{LeaNa}^{+} \mathrm{C}, \mathrm{MDA}$ and proline. Whereas, dominance effect was slightly higher than additive effect for 100-SW and CAT under control, 100 and $200 \mathrm{mM} \mathrm{NaCl}$, LeaK ${ }^{+} / \mathrm{Na}^{+} \mathrm{C}$ under control and $200 \mathrm{mM}$ salinity levels, GZnC, EL and POX under $100 \mathrm{mM}$ salinity level, RWC 
under $200 \mathrm{mM}$ salinity level and GY under non-saline condition (Table 4). Most of the studied traits exhibited high broad-sense heritabilities (more than $80 \%$ ) in all three salinity levels, indicating the environmental effects constitute a minor portion of the total phenotypic variation for these traits. The narrow sense heritability ranged from 0.03 for $\mathrm{LeaK}^{+} / \mathrm{Na}^{+} \mathrm{C}$ (at $200 \mathrm{mM}$ salinity level) to 0.69 for MDA (at $100 \mathrm{mM}$ salinity level). The average dominance ratio for all studied traits was greater than unity in the three salinity levels except $\mathrm{GFeC}, \mathrm{RFW}, \mathrm{LeaNa}{ }^{+} \mathrm{C}, \mathrm{POX}$ and proline under $200 \mathrm{mM}$ salinity level, GY, RWC and MDA under $100 \mathrm{mM}$ salinity level and RDW under control condition, indicating the predominance of the dominant gene action for these traits.

\section{Discussion}

A good strategy to improve and sustain bread wheat production in $\mathrm{Zn}$ and Fe-deficient soils with minimum or no $\mathrm{Zn}$ and $\mathrm{Fe}$ application and knowledge of genetic components of tolerance have become a research priority. Understanding the inheritance and genetic basis of $\mathrm{Zn}$ and Fe efficient uptake-related traits may assisted to achieve high seed yield and salinity tolerance of bread wheat.

In this study, significant differences among generations for the studied traits indicted the presence of enough genetic variation for further analyses. The GMA for control and saline conditions showed the insufficiency of additive-dominance model for all the traits except GFeC and RL under 100 and $200 \mathrm{mM} \mathrm{NaCl}$ levels, RFW, RDW, MDA and proline under control condition, RWC, EL and CAT under $100 \mathrm{mM} \mathrm{NaCl}$, and $\mathrm{GZnC}$ and $\mathrm{LeaK}^{+} \mathrm{C}$ under $200 \mathrm{mM} \mathrm{NaCl}$ condition, indicating the presence of epistatic gene interactions in genetic control of the traits involve in $\mathrm{Zn}$ and $\mathrm{Fe}$ efficient uptake.

For all the studied traits, mean effects (m) were highly significant and had more value than additive gene effects (d), which implicated on existence of common genes between the two parents and the sufficient genetic variation in these traits. Data presented here indicate that dominance effects were generally greater than additives, explaining that the studied traits were generally controlled by major genes under all salinity levels. The negative or positive sign for dominance effect is a function of $F_{1}$ generation mean value in relation to the mid parent value and indicates which parent is more contributing to the dominance effects. In the current study, the negative sign of dominance effect indicates that the $\mathrm{F}_{1}$ generation was more similar to the high $\mathrm{Zn}$ and Fe efficient parent "Roshan", because dominance is originated from the parent containing alleles responsible for high value of the given trait. Although this study identified the important gene effects controlling Zn and Fe efficient uptake-related traits, it 
should be noted that these traits are highly influenced by environmental conditions (high $\mathrm{G} \times \mathrm{E}$ interaction), stage of plant development, and particularly water status in bread wheat (Gomez-Becerra et al. 2010; Amiri et al. 2018) as in other crops (Phuke et al. 2017; Gaddameedi et al. 2018).

For GZnC and GFeC, only additive gene effect was significant under both non-saline and saline conditions. On the other hand, the additive gene effects included the major ratio of genetic variation of $\mathrm{GZnC}$ and $\mathrm{GFeC}$, suggesting necessity of effective selection in early generations. The sign of additive effects only reflects which parent is chosen as $\mathrm{P}_{1}$. In other word, considering the low value parent as $\mathrm{P}_{1}$ resulted in negative sign of additive effects and vis versa (Reid et al. 2016). The occurrence of significant additive effects for $\mathrm{GZnC}, \mathrm{GFeC}$ and $\mathrm{Zn} / \mathrm{Fe}$ efficient uptake-related traits in all three salinity levels are different from the reports of Gaddameedi et al. (2018) that stated grain iron and zinc concentration and agronomic traits are largely inherited by both additive and dominant in sorghum. Mukamuhirwa et al. (2015) found that additive and non-additive gene effects were important for $\mathrm{Zn}$ and Fe efficiency in common bean (Phaseolus vulgaris L.). On the basis of diallel analysis, Kumar et al. (2013) reported that additive and non-additive gene action were important for grain $\mathrm{Zn}$ and $\mathrm{Fe}$ concentration, respectively in sorghum and suggested that it is possible to improve grain Fe concentration through exploiting heterosis. Under field conditions, Velu et al. (2011) observed high ratio of combining ability variance components pointed out that the expression of grain $\mathrm{Fe}$ and $\mathrm{Zn}$ densities in pearl millet is governed predominantly by additive gene effects. Amiri et al. (2020) evidenced that dominant genetic effects mainly controlled GZnC and GFeC in bread wheat at the both crosses (Marvdasht $\times$ Rassoul and Marvdasht $\times$ Shahpasand). Chakraborti et al. (2010) reported non-additive gene effects for a large proportion of the variation in the kernel $\mathrm{Zn}$ and $\mathrm{Fe}$ concentrations in maize. Velu et al. (2017) studied the effects of GPC-B1 gene on grain $\mathrm{Zn}$ and $\mathrm{Fe}$ concentrations in wheat and reported that incorporation of the $G P C-B 1$ allele into commercial elite wheat germplasm increased grain $\mathrm{Zn}$ and $\mathrm{Fe}$ concentrations and remobilization of $\mathrm{Zn}$ and $\mathrm{Fe}$ from leaves to the grains. This action of GPC-B1 gene depended on the epistatic interaction with the background alleles and the environmental conditions.

Our results according with some other studies (e.g. Abu et al. 2017; Ravari et al. 2017) were shown that $\mathrm{Na}^{+}, \mathrm{K}^{+}$and $\mathrm{K}^{+} / \mathrm{Na}^{+}$are important traits in relation to salinity tolerance in wheat. James et al. (2011) shown that by introgression of $\mathrm{Naxl}$ and $\mathrm{Nax} 2$ genes from T. monococcum into hexaploid wheat, the $\mathrm{Na}^{+}$concentration is reduced in leaves and increased in leaf sheats, resulted in improving grain yield consequently. The results of the genomewide association by Genc et al. (2019) revealed Nax genes associated with high $\mathrm{Na}^{+}$accumulation, which may be 
involved in osmotic stress/tissue tolerance. They stated that the most modern bread wheat, especially MW\#293 genotype, are efficient in excluding $\mathrm{Na}^{+}$and introduced as new paradigm in breeding for salinity tolerance. Utilizing of breeding programs in modern genotypes with high intrinsic $\mathrm{Zn}$ and Fe leaded to facilitation of uptaking and transporting of these mineral nutrients from roots to the seeds under salinity stress.

The derived results showed the importance of the main and epistatic effects in $\mathrm{LeaNa}^{+} \mathrm{C}$, $\mathrm{LeaK}^{+} \mathrm{C}$ and LeaK ${ }^{+} / \mathrm{Na}^{+} \mathrm{C}$ inheritance and demonstrated their concern in designing of breeding programs to improve salt tolerance in wheat cultivars and populations. Wheras additive gene effects did not contribute to $\mathrm{Na}^{+}, \mathrm{K}^{+}$uptake and $\mathrm{K}^{+} / \mathrm{Na}^{+}$ ratio under saline and non-saline conditions, it seems that progress in selecting for low $\mathrm{Na}^{+}$uptake is very slow. These results are confirmed with Dashti et al. (2012) claimed complex epistatic effects for expressing $\mathrm{K}^{+} / \mathrm{Na}^{+}$ratio and leaf tissue $\mathrm{Na}^{+}$. Therefore, it would be necessary to postpone the selection to later generation to improving this trait. Contrarily, the mentioned results are disagreed with those reported by Marzooghian et al. (2014) who found negligible amount of epistatic gene effects comparing with additive and dominance effects for traits plant height, biomass, electrolyte leakage and $\mathrm{K}^{+} / \mathrm{Na}^{+}$ratio at different salinity conditions. Ali et al. (2014) also reported both additive and dominance genetic effects involved in controlling root length, biomass, grains per spike, 100-grain weight, $\mathrm{Na}^{+}, \mathrm{K}^{+}$and $\mathrm{K}^{+} / \mathrm{Na}^{+}$ratio under both saline and non-saline conditions in bread wheat.

Halward and Wynne (1991) claimed that with increasing of difference between parents, dominance and epistatic effects may play more significant roles in the inheritance of quantitative traits. In this study the parent named Navid variety with pedigree (Kirkpinar 79) 63-112/66-2×7C improved from Iran, while Roshan is an Iranian local cultivar. The pattern of gene effects for quantitative traits (especially yield and 100-SW) were similar under the non-saline and saline conditions explaining fixable and non-fixable gene actions are the basis for yield components. In contrast, under field conditions, Ravari et al. (2017) showed that in both crosses (Kavir $\times$ Arta and Kavir $\times$ Moghan3) under acidic soil conditions, the dominance effects were more important than additive and epistatic effects in the genetic control of grain yield. The differences between those results and our study may be due to differences in the level of salt stress, different genetic backgrounds, and/or screening environment used. Concerning thousand seed weight and grain yield, Mwadzingeni et al. (2018) observed significant effects for GCA under normal and drought-stress conditions indicated the influence of additive gene action.

Biochemical traits (e.g. CAT, POX, MDA and proline) perform important role in evaluating the salinity tolerance status of plants and could be used as an indirect selection index for screening $\mathrm{Zn} / \mathrm{Fe}$ uptake efficient plants 
(Tavallali et al. 2010; Saeidnejad et al. 2016; Babaei et al. 2017). Both fixable and non-fixable genetic effects under non-saline and saline conditions were important in inheritance of biochemical traits. Increased accumulation of antioxidants might improve abiotic stress in wheat by scavenging ROS (Ahmadi et al. 2018). Daneshbakhsh et al. (2013) found that under saline conditions, antioxidative defense mechanisms were activated to protect root membrane structure against oxidation. Plants potentially contain high $\mathrm{Zn}$ and Fe contents of seed could increase the activity of antioxidant enzymes, photosynthesis rate, and nutrient uptake under abiotic stress, ultimately could improve the yield performance (Faran et al. 2019).

According to Table 4, all the traits under non-saline and saline conditions showed high broad sense heritability and low to moderate narrow sense heritability, suggests that dominance gene action is more important than additives in controlling the majority of studied traits. Selection in the early segregation generations for such traits could be misleading, therefore, required further progeny testing. Such traits could be improved by crossing potential genotypes of segregating population by means of recombinant breeding approach (Samadia 2005). Similar results have been reported by Dashti et al. (2010) for $\mathrm{K}^{+} / \mathrm{Na}^{+}$ratio and $\mathrm{LeaK}^{+} \mathrm{C}$, Marzooghian et al. (2014) for $\mathrm{K}^{+} / \mathrm{Na}^{+}$ratio and $\mathrm{EL}$ and Amiri et al. (2020) for $\mathrm{GFeC}$ and $\mathrm{GZnC}$. The degree of dominance ranged from partial dominance ( 0.47 in proline at $200 \mathrm{Mm}$ salinity level) to over-dominance with the highest degree of dominance being 4.76 for $\mathrm{K}^{+} / \mathrm{Na}^{+}$ratio in the $200 \mathrm{Mm}$ salinity treatment (Table 4). With two exceptions in the control treatment, all values ranged from partial to complete dominance.

\section{Conclusions}

Based on our study, it is concluded that $\mathrm{Zn} / \mathrm{Fe}$ efficient uptake-related traits are controlled by additive and nonadditive genetic effects. When the contribution of additive effects is larger than non-additives, selection in the early segregation generations can be effective; otherwise, improvement of the characters needs intensive selection through later generations. Given that effective selection in early generations only occurs when genetic effects are additive and environmental effects have small impacts, this suggestion is appropriate. Finally, results of this study show that landraces would be excellent donors for combining beneficial salinity-tolerant and $\mathrm{Zn} / \mathrm{Fe}$ efficient uptake traits into a modern variety to improve wheat for $\mathrm{Zn} / \mathrm{Fe}$ deficient and salinity-prone environments. 


\section{Acknowledgements}

The authors gratefully acknowledge the laboratory facilities provided by Genomics \& Molecular Breeding Lab, Center of Excellence in Cereal Molecular Breeding, University of Tabriz, Iran.

\section{Compliance with ethical standards}

Conflict of interest The authors declare that there is no conflict of interests.

Author contribution statement Hossein Abbasi Holasou is written the manuscript, designed the experiment, analyzed the data and developed the idea. Seyed Siamak Alavi Kia is developed the idea, designed the experiment and written the manuscript. Seyed Abolghasem Mohammadi is written the manuscript, designed and developed the experiment. Mohammad Moghaddam Vahed is developed some part of the methods.

Availability of data and material The data are available on request.

Funding This research is part of the $\mathrm{PhD}$ thesis of the first author. This research was financially supported by the University of Tabriz.

\section{References}

Abbasi Holasou H, Alavi Kia SS, Mohammadi SA, Moghadam Vahed M (2019) Generation mean analysis in wheat (Triricum aestivum L.) under water deficit stress condition, using mixed linear models. J Bio Env Sci 14(2): $85-93$.

Abu H, Hafizur RH, Nurealam S, Khatun M, Rabiul I, Abdullah A (2017) Evaluation of wheat genotypes for salt tolerance based on some physiological traits. J Crop Sci Biotech 18: 333-340.

Ahmadi J, Pour-Aboughadareh A, Fabriki Ourang S, Mehrabi AA, Siddique KHM (2018) Wild relatives of wheat: Aegilops-Triticum accessions disclose differential antioxidative and physiological responses to water stress. Acta Physiol Plant https://doi.org/10.1007/s11738-018-2673-0

Ali Z, Khan AS, Karim I, Uzair M, Mahmood T, Saeed T, Sarwar S, Ghori N, Nisar Z, Sarwat SS, Qayyum A, Khan AA (2014) Generation mean effects, heterosis and heritabilities for seedling, adult and physiological salinity tolerance in spring wheat (Triticum aestivum). Int J Agric Biol 16: 1059-1066.

Amiri R, Bahraminejad S, Cheghamirza K (2018) Estimating genetic variation and genetic parameters for grain iron, zinc and protein concentrations in bread wheat genotypes grown in Iran. J Cereal Sci 80: 16-23. 
Amiri R, Bahraminejad S, Cheghamirza K, Arzani A (2020). Genetic analysis of iron and zinc concentrations in bread wheat grains. J Cereal Sci 95: 103077. https://doi.org/10.1016/j.jcs.2020.103077.

Babaei Kh, Seyed Sharifi R, Pirzad A, Khalizadeh R (2017) Effects of bio fertilizer and nano Zn-Fe oxide on physiological traits, antioxidant enzymes activity and yield of wheat (Triticum aestivum L.) under salinity stress. J Plant Interact 12(1): 381-389.

Balestre M, Von Pinho R, Brito A (2012) Bayesian inference to study genetic control of resistance to gray leaf spot in maize. Genet Mol Res 11:17-29.

Barrs HD, Weatherley PE (1962) A re-examination of the relative turgidity technique for estimating water deficits in leaves. Aust J Biol Sci 15(3): 413-428.

Bates LS, Waldren RP, Teare ID (1973) Rapid determination of free proline for water-stress studies. Plant Soil 39(1): 205-207.

Chakraborti M, Prasanna BM, Singh AM, Hossain F (2010) Generation mean analysis of kernel iron and zinc concentrations in maize (Zea mays). Indian J Agr Sci 80 (11): 956-959.

Chapman HD, Pratt PF (1961) Methods of Analysis for Soils, Plants and Waters. Riverside, CA: University of California, Division of Agriculture Science.

Daneshbakhsh B, Khoshgoftarmanesh AH, Shariatmadari H, Cakmak I (2013) Effect of zinc nutrition on salinityinduced oxidative damages in wheat genotypes differing in zinc deficiency tolerance. Acta Physiol Plant 35: 881-889.

Dashti H, Bihamta MR, Shirani H, Majidi MM (2012) Genetic analysis of salt tolerance in vegetative stage in wheat (Triticum aestivum). Plant Omics J 5(1): 19-23.

Dashti H, Naghavi MR, Tajabadipour A (2010) Genetic analysis of salinity tolerance in a bread wheat cross. J Agr Sci Tech 12: 347-356.

Faran M, Faroog M, Rehman A, Nawaz A, Kameran Saleem M, Ali N, Siddique KH (2019) High intrinsic seed Zn concentration improves abiotic stress tolerance in wheat. Plant Soil https://doi.org/10.1007/s11104-019$\underline{03977-3 .}$.

Food and Agriculture Organization (FAO) (2000) Global network on integrated soil management for sustainable use of salt-affected soils. Country specific salinity issues-Iran. FAO, Rome, http://www.fao.org/ag/agl/agll/spush/degrad.asp?country=iran. 
Food and Agriculture Organization (FAO) (2017) FAOSTAT. http://www.fao.org/faostat/en/\#data/QC.

Gaddameedi A, Ravikiran KT, Mohammed R, Phuked RM, Sadaiah K, Kavi Kishor PB, Ashok Kumar A (2018) Inheritance studies on grain iron and zinc concentration and agronomic traits in sorghum [Sorghum bicolor (L.) Moench]. J Cereal Sci 83: 252-258.

Genc Y, Taylor J, Lyons G, Li Y, Cheong J, Appelbee M, Oldach K, Sutton T (2019) Bread wheat with high salinity and sodicity tolerance. Front Plant Sci https://doi.org/10.3389/fpls.2019.01280

Gomez-Becerra HF, Yazici A, Ozturk L, Budak H, Peleg Z, Morgounov A, Fahima T, Saranga Y, Cakmak I (2010) Genetic variation and environmental stability of grain mineral nutrient concentrations in Triticum dicoccoides under five environments. Euphytica 171:39-52.

Gueta-Dahan Y, Yaniv Z, Zilinskas BA, Bea-Hayyim G (1997) Salt and oxidative stress: similar and specific response and their relation to salt tolerant in citrus. Planta 203: 460-469.

Heath RL, Packer L (1968) Photoperoxidation in isolated chloroplasts: I. Kinetics and stoichiometry of fatty acid peroxidation. Arch Biochem Biophys 125(1): 189-198.

Hallauer AR, Miranda JB (1988) Quantitative Genetics in Maize Breeding. Iowa State University Press, Ames, Iowa, IA, USA.

Halward TM, Wynne JC (1991) Generation mean analysis for productivity in two diverse peanut crosses. Theor Appl Genet 82: 784-792.

Hoagland DR, Arnon DI (1950) The water-culture method for growing plants without soil. California Agricultural Experiment Station 347.

James RA, Blake C, Byrt CS, Munns R (2011) Major genes for $\mathrm{Na}^{+}$exclusion, Nax1 and Nax2 (wheat HKT1;4 and HKT1;5) decrease $\mathrm{Na}^{+}$accumulation in bread wheat leaves under saline and waterlogged conditions. J Exp Bot 62(8): 2939-2947. https://doi.org/10.1093/jxb/err003.

Khoshgoftarmanesh AH, Shariatmadari H, Karimian N (2006a) Responses of wheat genotypes to zinc fertilization under saline soil conditions. J Plant Nutr 29:1543-1556.

Khoshgoftarmanesh AH, Shariatmadari H, Karimian N, Kalbasi M, Van Der Zee SEATM (2006b) Cadmium and zinc in saline soil solutions and their concentrations in wheat. Soil Sci Soc Am J 70:582-589.

Kumar AA, Reddy BVS, Ramaiah B, Sahrawat KL, Pfeiffer WH (2013) Gene effects and heterosis for grain iron and zinc concentration in sorghum [Sorghum bicolor (L.) Moench]. Field Crop Res 146: 86-95. 
Liu DY, Liu YM, Zhang W, Chen XP, Zou ChQ (2019) Zinc uptake, translocation, and remobilization in winter wheat as affected by soil application of $\mathrm{Zn}$ fertilizer. Front Plant Sci https://doi.org/10.3389/fpls.2019.00426.

Lutts S, Kinet JM, Bouharmont J (1996) NaCl-induced senescence in leaves of rice (Oryza sativa $\mathrm{L}$.) cultivars differing in salinity resistance. Ann Bot 78: 389-398.

Marzooghian A, Moghaddam M, Toorchi M, Shakiba MR (2014) Investigation of genetic structure and gene action in bread wheat affected by salt stress. Int J Biosci 5: 173-181.

Mather K, Jinks JL (1982) Biometrical genetics: the study of continuous variation, 3rd edn. Springer US, New York. Mather K, Jinks JL (1971) Biometrical Genetics, 2nd ed., Chapman and Hall, London, UK.

Moroni JS, Briggs KG, Blenis PV, Taylor GJ (2013) Generation mean analysis of spring wheat (Triticum aestivum L.) seedlings tolerant to high levels of manganese. Euphytica 189: 89-100. https://doi.org/10.1007/s10681012-0714-0

Mukamuhirwa F, Tusiime G, Mukankusi MC (2015) Inheritance of high iron and zinc concentration in selected bean varieties. Euphytica 205: 349-360.

Munns R, Tester M (2008) Mechanisms of salinity tolerance. Annu Rev Plant Biol 59:651-681.

Mwadzingeni L, Shimelis H, Tsilo TJ (2018) Combining ability and gene action controlling yield and yield components in bread wheat (Triticum aestivum L.) under drought-stressed and non-stressed conditions. Plant Breeding 137(4): 502-513. https://doi.org/10.1111/pbr.12609.

Peleg Z, Cakmak I, Ozturk L, Yazici A, Jun Y, Budak H, Korol AB, Fahima T, Saranga Y (2009) Quantitative trait loci conferring grain mineral nutrient concentrations in durum wheat-wild emmer wheat RIL population. Theor Appl Genet 119: 353-369.

Pfeiffer WH, McClafferty B (2007) HarvestPlus: breeding crops for better nutrition. Crop Sci 47: 88-105.

Phuke RM, Anuradha K, Radhika K, Jabeen F, Anuradha Gh, Ramesh T, Hariprasanna K, Mehtre ShP, Deshpande SP, Anil G, Das RR, Rathore A, Hash T, Reddy BVS, Kumar AA (2017) Genetic variability, genotype × environment interaction, correlation, and GGE biplot analysis for grain Iron and Zinc concentration and other agronomic traits in RIL population of Sorghum (Sorghum bicolor L. Moench). Front Plant Sci https://doi.org/10.3389/fpls.2017.00712.

Piepho HP, Mohring J (2010) Generation means analysis using mixed models. Crop Science 50:1674-1680. 
Poustini K, Siosemardeh A (2004) Ion distribution in wheat cultivars in response to salinity stress. Field Crop Res 85: $125-133$.

Qadir M, Qureshi AS, Cheraghi SAM (2008) Extent and characterisation of salt-affected soils in Iran and strategies for their amelioration and management. Land Degrad Dev 19: 214-227. https://doi.org/10.1002/ldr.818.

Ravari SZ, Dehghani H, Naghavi H (2017) Study of genetic control of salinity tolerance in bread wheat cv. Kavirusing generation mean analysis. Crop Breeding Journal 7(2): 57-66. https://doi.org/10.22092/cbj.2018.115180.1010.

Rehman A, Farooq M, Ozturk L, Asif M, Siddique KHM (2017) Zinc nutrition in wheat-based cropping systems. Plant Soil https://doi.org/10.1007/s11104-017-3507-3

Reid LM, Zhu X, Jindal KK, Kebede AZ, Wu J, Morrison MJ (2016) Increasing stalk sucrose in sugar corn (Zea mays L.): genetic analysis and preliminary breeding. Euphytica https://doi.org/10.1007/s10681-016-1669-3.

Saeidnejad AH, Kafi M, Pessarakli M (2016) Interactive Effects of salinity stress and Zn availability on physiological properties, antioxidants activity and micronutrients' content of wheat (Triticum aestivum) plants. Commun Soil Sci Plant Anal 47(8): 1048-1057. https://doi.org/10.1080/00103624.2016.1165831

Samadia DK (2005) Genetic variability studies in Lasora (Cordia Myxa Roxb.). Indian Journal of Plant and Genetic Resources 18(3): 236-240.

SAS Institute (2007) The SAS system for Windows, version 9.2. SAS Institute Inc, Cary.

Sharifi-Soltani N, Alavi-Kia SS, Moghaddam Vahed M, Aharizad S (2016) Genetic variation of bread wheat varieties in terms of $\mathrm{Zn}$ and $\mathrm{Fe}$ accumulation in grain under zinc foliar application. Biological Forum-An International Journal 8: 391-396.

Singh BK, Sharma SR, Singh B (2010) Antioxidant enzymes in cabbage: variability and inheritance of superoxide dismutase, peroxidase and catalase. Scientia Horticulturae 124: 9-13.

Tavallali V, Rahemi M, Eshghi S, Kholdebarin B, Ramezanian A (2010) Zinc alleviates salt stress and increase antioxidant enzyme activity in the leaves of pistachio (Pistacia vera L. Badami) seedlings. Turk $\mathbf{J}$ Agric For 34: 349-359. https://doi.org/10.3906/tar-0905-10.

Velu G, Ortiz-Monasterio I, Cakmak I, Hao Y, Singh RP (2014) Biofortification strategies to increase grain zinc and iron concentrations in wheat. J Cereal Sci 59:365-372. 
Velu G, Rai KN, Muralidharan V, Longvah T, Crossa J (2011) Gene effects and heterosis for grain iron and zinc density in pearl millet (Pennisetum glaucum (L.) R. Br). Euphytica 180: 251-259.

Velu G, Singh RP, Cardenas ME, Wu B, Carlos G, Ortiz-Monasterio I (2017) Characterization of grain protein content gene (GPC-Bl) introgression lines and its potential use in breeding for enhanced grain zinc and iron concentration in spring wheat. Acta Physiol Plant 39: 212. https://doi.org/10.1007/s11738-017-2509-3.

Zadoks JC, Chang TT, Konzak CF (1974) A decimal code for the growth stages of cereals. Weed Res 14:415-421.

Wright S (1968) Evolution and the Genetic of Population. Vol. 1. Genetics and Biometrics Foundations, University of Chicago Press, Chicago, IL, USA 
Table 1 Analysis of variance for studied traits in bread wheat under Control (C), 100 and $200 \mathrm{mM} \mathrm{NaCl}$

\begin{tabular}{|c|c|c|c|c|c|c|c|}
\hline \multirow[t]{2}{*}{ S.O.V } & \multirow[t]{2}{*}{ df } & \multicolumn{6}{|c|}{ Mean Square } \\
\hline & & $\mathrm{GFeC}(\mathrm{mg} / \mathrm{kg})$ & $\mathrm{GZnC}(\mathrm{mg} / \mathrm{kg})$ & 100-SW (g) & GY (g) & RL & RFW \\
\hline Rep & 2 & $82.03^{\mathrm{ns}}$ & $23.97^{\mathrm{ns}}$ & $0.01^{\mathrm{ns}}$ & $0.02^{\mathrm{ns}}$ & $0.78^{\mathrm{ns}}$ & $0.04^{* *}$ \\
\hline Salinity & 2 & $950.19^{* *}$ & $484.09^{* *}$ & $0.91^{* *}$ & $2.17^{* *}$ & $18.06^{* *}$ & $0.24^{* *}$ \\
\hline Generation & 5 & $1161.85^{* *}$ & $710.49^{* *}$ & $5.27^{* *}$ & $1.04^{* *}$ & $461.93^{* *}$ & $2.83^{* *}$ \\
\hline Salinity $\times$ Generation & 10 & $44.99^{\mathrm{ns}}$ & $29.32^{\mathrm{ns}}$ & $0.03^{\mathrm{ns}}$ & $0.16^{*}$ & $2.23^{* *}$ & $0.01^{* *}$ \\
\hline Error & 34 & 72.55 & 15.47 & 0.02 & 0.06 & 0.54 & 0.003 \\
\hline C.V (\%) & & 12.27 & 6.12 & 5.35 & 14.73 & 5.44 & 4.76 \\
\hline
\end{tabular}

$\mathrm{ns}, *, * *$ : non-significant and significant at 0.05 and 0.01 probability levels, respectively.

Grain Fe Concentration (GFeC), Grain Zn Concentration (GZnC), weight of 100 grains (100-SW), Grain yield per plant (GY), Root length (RL), Root Fresh Weight (RFW).

Table 1 (Continued)

\begin{tabular}{|c|c|c|c|c|c|c|}
\hline \multirow[t]{2}{*}{ S.O.V } & \multirow[t]{2}{*}{ Df } & \multicolumn{5}{|c|}{ Mean Square } \\
\hline & & RDW & RWC & EL & $\mathrm{LeaNa}+\mathrm{C}$ & $\mathrm{LeaK}+\mathrm{C}$ \\
\hline Rep & 2 & $0.005^{\text {** }}$ & $2.41^{\mathrm{ns}}$ & $3.05^{\mathrm{ns}}$ & $0.59^{\mathrm{ns}}$ & $1.16^{\mathrm{ns}}$ \\
\hline Salinity & 2 & $0.034^{* *}$ & $45.03^{* *}$ & $213.80^{* *}$ & $70.39^{* *}$ & $391.32^{* *}$ \\
\hline Generation & 5 & $0.686^{* *}$ & $75.74^{* *}$ & $2440.15^{* *}$ & $82.22^{* *}$ & $494.93^{* *}$ \\
\hline Salinity $\times$ Generation & 10 & $0.003^{* *}$ & $5.04^{*}$ & $42.35^{* *}$ & $3.53^{* *}$ & $29.59^{* *}$ \\
\hline Error & 34 & 0.0006 & 2.001 & 7.58 & 0.29 & 5.03 \\
\hline C.V (\%) & & 6.65 & 2.05 & 7.57 & 6.77 & 6.87 \\
\hline
\end{tabular}

$\mathrm{ns}, *, * *$ : non-significant and significant at 0.05 and 0.01 probability levels, respectively.

Root Dry Weight (RDW), Relative Water Content (RWC), Electric Leakage (EL), Leaf $\mathrm{Na}^{+}$Concentration $\left(\mathrm{LeaNa}^{+} \mathrm{C}\right)$, Leaf $\mathrm{K}^{+}$Concentration $\left(\mathrm{LeaK}^{+} \mathrm{C}\right)$

Table 1 (Continued)

\begin{tabular}{|c|c|c|c|c|c|c|}
\hline \multirow[t]{2}{*}{ S.O.V } & \multirow[t]{2}{*}{ Df } & \multicolumn{5}{|c|}{ Mean Square } \\
\hline & & $\mathrm{LeaK}^{+} / \mathrm{Na}^{+} \mathrm{C}$ & CAT & POX & MDA & Proline \\
\hline Rep & 2 & $0.73^{\mathrm{ns}}$ & $0.19^{\mathrm{ns}}$ & $3.98^{\mathrm{ns}}$ & $0.0002^{\mathrm{ns}}$ & $0.05^{\mathrm{ns}}$ \\
\hline Salinity & 2 & $47.14^{* *}$ & $46.48^{* *}$ & $121.15^{* *}$ & $0.008^{* *}$ & $2.17^{* *}$ \\
\hline Generation & 5 & $79.83^{* *}$ & $78.65^{* *}$ & $345.97^{* *}$ & $0.017^{* *}$ & $3.15^{* *}$ \\
\hline Salinity $\times$ Generation & 10 & $3.63^{* *}$ & $8.42^{* *}$ & $22.68^{* *}$ & $0.002^{* *}$ & $0.06^{\mathrm{ns}}$ \\
\hline Error & 34 & 0.62 & 0.87 & 2.55 & 0.0003 & 0.05 \\
\hline C.V $(\%)$ & & 15.35 & 10.03 & 4.05 & 2.98 & 6.64 \\
\hline
\end{tabular}

$\mathrm{ns}, *, * *$ : non-significant and significant at 0.05 and 0.01 probability levels, respectively.

$\mathrm{K}^{+} / \mathrm{Na}^{+}$Concentration ratio $\left(\mathrm{LeaK}^{+} / \mathrm{Na}^{+} \mathrm{C}\right)$, Catalase (CAT), Peroxidase (POX), Malondialdehyde (MDA), Proline content. 
Table 2 Mean and its standard error of six generations for different traits of bread wheat

\begin{tabular}{lllllll}
\hline & \multicolumn{2}{c}{ GFeC } & \multicolumn{3}{c}{ GZnC } \\
& C & 100 & 200 & C & 100 & 200 \\
\hline P1 & $66.42 \pm 3.38$ & $59.08 \pm 1.21$ & $59.36 \pm 3.24$ & $50.24 \pm 4.52$ & $51.22 \pm 1.59$ & $38.63 \pm 0.69$ \\
P2 & $103.22 \pm 8.14$ & $79.63 \pm 3.38$ & $79.20 \pm 2.85$ & $67.12 \pm 2.31$ & $61.88 \pm 1.89$ & $61.26 \pm 1.95$ \\
F1 & $82.24 \pm 4.19$ & $67.29 \pm 1.50$ & $61.02 \pm 2.45$ & $60.73 \pm 1.52$ & $53.34 \pm 3.80$ & $42.63 \pm 1.91$ \\
F2 & $72.90 \pm 1.61$ & $60.17 \pm 0.92$ & $61.47 \pm 2.21$ & $52.38 \pm 1.42$ & $41.20 \pm 1.29$ & $40.40 \pm 1.43$ \\
BC1 & $67.40 \pm 3.04$ & $57.51 \pm 1.59$ & $52.25 \pm 1.16$ & $51.26 \pm 2.67$ & $41.95 \pm 1.45$ & $36.97 \pm 1.40$ \\
BC2 & $79.70 \pm 3.42$ & $70.44 \pm 6.97$ & $70.36 \pm 7.86$ & $58.14 \pm 3.79$ & $50.31 \pm 1.92$ & $44.64 \pm 1.27$ \\
\hline
\end{tabular}

Table 2 (Continued)

\begin{tabular}{lllllll}
\hline & & $100-S W$ & & GY \\
& C & 100 & 200 & C & 100 & 200 \\
\hline P1 & $2.97 \pm 0.12$ & $2.31 \pm 0.04$ & $1.61 \pm 0.10$ & $1.31 \pm 0.04$ & $1.61 \pm 0.08$ & $0.79 \pm 0.09$ \\
P2 & $3.25 \pm 0.09$ & $2.98 \pm 0.08$ & $2.44 \pm 0.05$ & $2.02 \pm 0.12$ & $2.24 \pm 0.17$ & $1.74 \pm 0.06$ \\
F1 & $3.75 \pm 0.10$ & $3.29 \pm 0.12$ & $2.64 \pm 0.07$ & $2.90 \pm 0.28$ & $2.87 \pm 0.20$ & $1.92 \pm 0.10$ \\
F2 & $3.32 \pm 0.04$ & $2.78 \pm 0.04$ & $2.20 \pm 0.03$ & $1.77 \pm 0.06$ & $1.79 \pm 0.06$ & $1.55 \pm 0.05$ \\
BC1 & $3.10 \pm 0.06$ & $2.42 \pm 0.07$ & $2.07 \pm 0.03$ & $1.52 \pm 0.12$ & $1.18 \pm 0.08$ & $1.32 \pm 0.04$ \\
BC2 & $3.22 \pm 0.05$ & $2.72 \pm 0.10$ & $2.16 \pm 0.05$ & $1.62 \pm 0.12$ & $1.55 \pm 0.12$ & $1.36 \pm 0.05$ \\
\hline
\end{tabular}

Table 2 (Continued)

\begin{tabular}{lllllll}
\hline & \multicolumn{2}{c}{$\mathrm{RL}$} & & \multicolumn{2}{c}{ RFW } \\
& $\mathrm{C}$ & 100 & 200 & $\mathrm{C}$ & 100 & 200 \\
\hline P1 & $16.28 \pm 0.34$ & $12.05 \pm 0.25$ & $5.77 \pm 0.29$ & $1.39 \pm 0.02$ & $0.87 \pm 0.03$ & $0.49 \pm 0.04$ \\
P2 & $18.97 \pm 0.58$ & $15.43 \pm 0.28$ & $9.36 \pm 0.29$ & $1.67 \pm 0.03$ & $1.26 \pm 0.04$ & $1.04 \pm 0.04$ \\
F1 & $21.75 \pm 0.65$ & $14.09 \pm 0.35$ & $10.03 \pm 0.23$ & $1.73 \pm 0.04$ & $1.23 \pm 0.03$ & $1.07 \pm 0.03$ \\
F2 & $17.72 \pm 0.25$ & $13.73 \pm 0.22$ & $8.86 \pm 0.23$ & $1.65 \pm 0.02$ & $1.16 \pm 0.03$ & $0.82 \pm 0.04$ \\
BC1 & $16.95 \pm 0.43$ & $13.19 \pm 0.34$ & $7.68 \pm 0.26$ & $1.53 \pm 0.04$ & $0.89 \pm 0.03$ & $0.75 \pm 0.02$ \\
BC2 & $18.98 \pm 0.52$ & $14.95 \pm 0.37$ & $8.28 \pm 0.28$ & $1.67 \pm 0.04$ & $1.04 \pm 0.04$ & $0.80 \pm 0.03$ \\
\hline
\end{tabular}

Table 2 (Continued)

\begin{tabular}{|c|c|c|c|c|c|c|}
\hline & \multicolumn{3}{|c|}{ RDW } & \multicolumn{3}{|c|}{ RWC } \\
\hline & $\mathrm{C}$ & 100 & 200 & $\mathrm{C}$ & 100 & 200 \\
\hline P1 & $0.38 \pm 0.01$ & $0.42 \pm 0.01$ & $0.09 \pm 0.01$ & $67.63 \pm 0.43$ & $65.51 \pm 0.56$ & $65.95 \pm 0.38$ \\
\hline P2 & $0.50 \pm 0.02$ & $0.57 \pm 0.02$ & $0.20 \pm 0.03$ & $73.00 \pm 0.65$ & $69.95 \pm 0.62$ & $71.92 \pm 0.63$ \\
\hline $\mathrm{F} 1$ & $0.51 \pm 0.02$ & $0.56 \pm 0.02$ & $0.30 \pm 0.02$ & $72.40 \pm 0.65$ & $69.65 \pm 0.37$ & $69.15 \pm 2.11$ \\
\hline $\mathrm{F} 2$ & $0.45 \pm 0.01$ & $0.51 \pm 0.01$ & $0.10 \pm 0.00$ & $73.31 \pm 0.41$ & $69.61 \pm 0.47$ & $66.91 \pm 0.40$ \\
\hline BC1 & $0.43 \pm 0.02$ & $0.45 \pm 0.02$ & $0.08 \pm 0.00$ & $69.13 \pm 0.54$ & $66.45 \pm 0.71$ & $62.74 \pm 0.58$ \\
\hline $\mathrm{BC} 2$ & $0.47 \pm 0.01$ & $0.49 \pm 0.01$ & $0.09 \pm 0.00$ & $71.88 \pm 0.65$ & $67.78 \pm 0.77$ & $67.32 \pm 0.42$ \\
\hline
\end{tabular}

Table 2 (Continued)

\begin{tabular}{lllllll}
\hline & \multicolumn{2}{c}{ EL } & & & LeaNa ${ }^{+} \mathrm{l}$ \\
& $\mathrm{C}$ & 100 & 200 & $\mathrm{C}$ & 100 & 200 \\
\hline P1 & $28.57 \pm 0.74$ & $43.11 \pm 1.26$ & $60.13 \pm 0.99$ & $9.80 \pm 0.43$ & $12.80 \pm 0.60$ & $16.59 \pm 0.57$ \\
P2 & $21.77 \pm 0.68$ & $33.42 \pm 1.24$ & $42.20 \pm 1.07$ & $4.48 \pm 0.32$ & $5.74 \pm 0.24$ & $6.19 \pm 0.23$ \\
F1 & $22.62 \pm 0.73$ & $27.45 \pm 1.50$ & $40.69 \pm 1.14$ & $5.18 \pm 0.31$ & $5.68 \pm 0.28$ & $7.42 \pm 0.31$ \\
F2 & $30.28 \pm 1.00$ & $29.77 \pm 0.72$ & $45.04 \pm 0.84$ & $4.89 \pm 0.14$ & $6.02 \pm 0.17$ & $9.11 \pm 0.28$ \\
BC1 & $26.17 \pm 0.95$ & $34.63 \pm 1.40$ & $55.14 \pm 1.97$ & $6.14 \pm 0.32$ & $8.47 \pm 0.43$ & $12.56 \pm 0.55$ \\
BC2 & $27.00 \pm 1.08$ & $35.50 \pm 1.89$ & $50.75 \pm 0.98$ & $5.21 \pm 0.24$ & $7.25 \pm 0.38$ & $9.31 \pm 0.46$ \\
\hline
\end{tabular}


Table 2 (Continued)

\begin{tabular}{lllllll}
\hline & \multicolumn{3}{c}{ LeaK $^{+} \mathrm{C}$} & & \multicolumn{3}{c}{$\mathrm{LeaK}^{+} / \mathrm{Na}^{+} \mathrm{C}$} \\
& $\mathrm{C}$ & 100 & 200 & $\mathrm{C}$ & 100 & 200 \\
\hline P1 & $28.97 \pm 1.52$ & $26.36 \pm 1.46$ & $22.66 \pm 0.94$ & $3.01 \pm 0.19$ & $2.12 \pm 0.17$ & $1.39 \pm 0.08$ \\
P2 & $55.87 \pm 2.06$ & $42.40 \pm 1.88$ & $34.84 \pm 1.27$ & $13.13 \pm 0.93$ & $7.52 \pm 0.42$ & $5.72 \pm 0.30$ \\
F1 & $38.84 \pm 2.37$ & $31.07 \pm 1.35$ & $27.97 \pm 1.04$ & $7.84 \pm 0.75$ & $5.67 \pm 0.44$ & $3.81 \pm 0.15$ \\
F2 & $40.86 \pm 0.83$ & $36.37 \pm 0.83$ & $28.41 \pm 0.88$ & $8.61 \pm 0.31$ & $6.20 \pm 0.21$ & $3.22 \pm 0.15$ \\
BC1 & $30.66 \pm 1.10$ & $29.11 \pm 1.82$ & $25.16 \pm 1.15$ & $5.13 \pm 0.29$ & $3.51 \pm 0.26$ & $2.05 \pm 0.14$ \\
BC2 & $33.16 \pm 1.12$ & $28.64 \pm 0.23$ & $26.50 \pm 1.54$ & $6.50 \pm 0.36$ & $4.05 \pm 0.23$ & $2.93 \pm 0.25$ \\
\hline
\end{tabular}

Table 2 (Continued)

\begin{tabular}{lllllll}
\hline & \multicolumn{3}{c}{ CAT } & \multicolumn{3}{c}{ POX } \\
& C & 100 & 200 & C & 100 & 200 \\
\hline P1 & $5.73 \pm 0.26$ & $6.08 \pm 0.29$ & $7.93 \pm 0.39$ & $30.67 \pm 0.76$ & $34.42 \pm 0.76$ & $38.17 \pm 1.09$ \\
P2 & $8.09 \pm 0.42$ & $13.31 \pm 0.59$ & $17.34 \pm 0.39$ & $40.00 \pm 0.56$ & $44.50 \pm 0.79$ & $51.33 \pm 0.78$ \\
F1 & $7.86 \pm 0.27$ & $11.00 \pm 0.57$ & $13.55 \pm 0.68$ & $34.33 \pm 0.67$ & $40.67 \pm 1.18$ & $49.58 \pm 1.00$ \\
F2 & $7.59 \pm 0.20$ & $9.90 \pm 0.28$ & $9.21 \pm 0.27$ & $35.14 \pm 0.46$ & $36.72 \pm 0.52$ & $45.56 \pm 0.73$ \\
BC1 & $6.77 \pm 0.51$ & $7.39 \pm 0.39$ & $8.87 \pm 0.65$ & $38.17 \pm 0.67$ & $38.08 \pm 1.16$ & $38.33 \pm 0.97$ \\
BC2 & $6.24 \pm 0.28$ & $11.42 \pm 0.56$ & $10.10 \pm 0.47$ & $36.08 \pm 0.67$ & $35.33 \pm 0.99$ & $42.67 \pm 0.83$ \\
\hline
\end{tabular}

Table 2 (Continued)

\begin{tabular}{lllllll}
\hline & \multicolumn{3}{c}{ MDA } & \multicolumn{3}{c}{ Proline } \\
& $\mathrm{C}$ & 100 & 200 & $\mathrm{C}$ & 100 & 200 \\
\hline P1 & $0.52 \pm 0.01$ & $0.61 \pm 0.01$ & $0.63 \pm 0.01$ & $1.98 \pm 0.13$ & $2.38 \pm 0.14$ & $2.94 \pm 0.09$ \\
P2 & $0.64 \pm 0.01$ & $0.64 \pm 0.01$ & $0.68 \pm 0.01$ & $3.31 \pm 0.11$ & $3.87 \pm 0.09$ & $4.06 \pm 0.11$ \\
F1 & $0.58 \pm 0.01$ & $0.56 \pm 0.01$ & $0.64 \pm 0.01$ & $3.03 \pm 0.13$ & $3.74 \pm 0.12$ & $3.92 \pm 0.10$ \\
F2 & $0.58 \pm 0.01$ & $0.58 \pm 0.01$ & $0.59 \pm 0.01$ & $2.81 \pm 0.10$ & $3.72 \pm 0.06$ & $3.90 \pm 0.07$ \\
BC1 & $0.55 \pm 0.01$ & $0.52 \pm 0.01$ & $0.61 \pm 0.01$ & $2.68 \pm 01.7$ & $2.99 \pm 0.13$ & $3.07 \pm 0.11$ \\
BC2 & $0.57 \pm 0.01$ & $0.57 \pm 0.01$ & $0.63 \pm 0.01$ & $2.95 \pm 0.16$ & $3.55 \pm 0.09$ & $3.76 \pm 0.12$ \\
\hline
\end{tabular}


Table 3 Mean, additive, dominance and epistatic effects, and type of non-allelic interaction regarding $\mathrm{Zn}$ and $\mathrm{Fe}$ efficiency indices and shoot and root traits a for the cross Navid $\times$ Roshan, under salinity stress

\begin{tabular}{|c|c|c|c|c|c|c|c|}
\hline Traits & $\mathrm{m}$ & [d] & [h] & [i] & [j] & {$[1]$} & Wald-F \\
\hline \multicolumn{8}{|l|}{$\mathrm{GFeC}$} \\
\hline $\mathrm{C}$ & $81.18^{*} \pm 13.35$ & $-10.85^{*} \pm 3.17$ & $-44.26^{\mathrm{ns}} \pm 34.91$ & $-4.26^{\mathrm{ns}} \pm 13.01$ & $-2.59^{\mathrm{ns}} \pm 1.08$ & $46.85^{\mathrm{ns}} \pm 23.77$ & $3.46^{*}$ \\
\hline S1 & $80.22^{*} \pm 15.09$ & $-21.34^{* \star} \pm 2.51$ & $-38.02^{\mathrm{ns}_{ \pm}} \pm 17.22$ & - & - & - & $1.02^{\mathrm{ns}}$ \\
\hline $\mathrm{S} 2$ & $78.39^{\star} \pm 27.31$ & $-10.22^{*} \pm 3.73$ & $-52.68^{\mathrm{ns}} \pm 36.56$ & - & - & - & $0.38^{\mathrm{ns}}$ \\
\hline \multicolumn{8}{|l|}{$\mathrm{GZnC}$} \\
\hline $\mathrm{C}$ & $58.47^{\star \star} \pm 10.79$ & $-10.90^{*} \pm 1.29$ & $16.44^{\mathrm{ns}} \pm 10.72$ & $11.80^{\mathrm{ns}} \pm 10.68$ & $6.99^{\mathrm{ns}} \pm 5.01$ & $-0.41^{\mathrm{ns}} \pm 0.38$ & $3.36^{*}$ \\
\hline $\mathrm{S} 1$ & $53.66^{* \star} \pm 11.61$ & $-5.24^{*} \pm 2.11$ & $-1.93^{\mathrm{ns}} \pm 1.52$ & $18.35^{\mathrm{ns}} \pm 11.39$ & $-6.74^{\mathrm{ns}} \pm 5.22$ & $19.90^{\mathrm{ns}} \pm 18.21$ & $13.43^{* *}$ \\
\hline $\mathrm{S} 2$ & $38.07^{\star \star} \pm 3.24$ & $-7.13^{*} \pm 3.07$ & $-3.33^{\mathrm{ns}} \pm 1.41$ & - & - & - & $1.08^{\mathrm{ns}}$ \\
\hline \multicolumn{8}{|l|}{$100-\mathrm{SW}$} \\
\hline $\mathrm{C}$ & $3.91^{* \star} \pm 0.26$ & $-0.13^{\mathrm{ns}} \pm 0.08$ & $-2.13^{* *} \pm 0.69$ & $-0.76^{\star *} \pm 0.25$ & $0.04^{\mathrm{ns}} \pm 0.32$ & $2.01^{* \star} \pm 0.48$ & $4.65^{* *}$ \\
\hline S1 & $3.55^{* \star} \pm 0.36$ & $-0.34^{* *} \pm 0.06$ & $-2.55^{*} \pm 1.05$ & $-0.83^{*} \pm 0.36$ & $-0.01^{\mathrm{ns}} \pm 0.04$ & $2.37^{\star *} \pm 0.70$ & $6.79^{* *}$ \\
\hline $\mathrm{S} 2$ & $2.37^{* *} \pm 0.32$ & $-0.39^{\star *} \pm 0.05$ & $-0.96^{\mathrm{ns}} \pm 0.77$ & $-0.36^{\mathrm{ns}} \pm 0.31$ & $0.57^{*} \pm 0.22$ & $1.17^{\mathrm{ns}} \pm 0.49$ & $10.00^{* *}$ \\
\hline \multicolumn{8}{|l|}{ GY } \\
\hline $\mathrm{C}$ & $3.62^{* \star} \pm 0.57$ & $-0.36^{*} \pm 0.16$ & $-3.69^{n s} \pm 2.31$ & $-0.94^{\mathrm{ns}} \pm 0.92$ & $0.51^{\mathrm{ns}} \pm 0.65$ & $3.98^{*} \pm 1.46$ & $7.20^{* *}$ \\
\hline $\mathrm{S} 1$ & $2.63^{* \star} \pm 0.94$ & $-0.31^{*} \pm 0.13$ & $-6.28^{* *} \pm 1.49$ & $-1.59^{*} \pm 0.55$ & $-0.05^{\mathrm{ns}} \pm 0.49$ & $5.63^{\star \star} \pm 1.01$ & $16.54^{* *}$ \\
\hline $\mathrm{S} 2$ & $2.13^{* \star} \pm 0.41$ & $-0.42^{\star \star} \pm 0.06$ & $-2.07^{n s} \pm 0.97$ & $-0.87^{\mathrm{ns}} \pm 0.40$ & $0.77^{*} \pm 0.26$ & $1.80^{*} \pm 0.60$ & $6.22^{*}$ \\
\hline \multicolumn{8}{|l|}{ RL } \\
\hline $\mathrm{C}$ & $14.35^{\star \star} \pm 2.08$ & $-1.11^{*} \pm 0.38$ & $5.92^{\mathrm{ns}} \pm 5.67$ & $3.41^{\mathrm{ns}} \pm 2.03$ & $-3.43^{\mathrm{ns}} \pm 1.85$ & $1.77^{\mathrm{ns}} \pm 3.78$ & $5.87^{\star}$ \\
\hline S1 & $12.47^{\star \star} \pm 1.91$ & $-1.67^{\star \star} \pm 0.26$ & $4.43^{\mathrm{ns}} \pm 4.90$ & - & - & - & $0.23^{\mathrm{ns}}$ \\
\hline $\mathrm{S} 2$ & $11.46^{\star \star} \pm 1.77$ & $-1.69^{* \star} \pm 0.23$ & $-8.58^{\mathrm{ns}} \pm 4.37$ & - & - & - & $3.15^{\mathrm{ns}}$ \\
\hline \multicolumn{8}{|l|}{ RFW } \\
\hline $\mathrm{C}$ & $1.91^{* \star} \pm 0.18$ & $-0.14^{\star \star} \pm 0.02$ & $-0.63^{\mathrm{ns}} \pm 0.44$ & - & - & - & $0.83^{\mathrm{ns}}$ \\
\hline $\mathrm{S} 1$ & $1.86^{* \star} \pm 0.16$ & $-0.18^{* *} \pm 0.02$ & $-2.32^{* *} \pm 0.45$ & $-0.85^{* *} \pm 0.17$ & $0.009^{\mathrm{ns}} \pm 0.02$ & $1.66^{* *} \pm 0.28$ & $14.75^{* *}$ \\
\hline $\mathrm{S} 2$ & $0.96^{* \star} \pm 0.20$ & $-0.28^{* \star} \pm 0.03$ & $-0.77^{\mathrm{ns}} \pm 0.46$ & $-0.23^{\mathrm{ns}} \pm 0.20$ & $0.51^{* *} \pm 0.10$ & $0.84^{*} \pm 0.27$ & $13.79^{* *}$ \\
\hline \multicolumn{8}{|l|}{ RDW } \\
\hline $\mathrm{C}$ & $0.63^{* \star} \pm 0.0 .5$ & $-0.05^{\star *} \pm 0.01$ & $-0.18^{\mathrm{ns}} \pm 0.15$ & - & - & - & $1.64^{\mathrm{ns}}$ \\
\hline S1 & $0.49^{\star \star} \pm 0.02$ & $-0.07^{\star *} \pm 0.009$ & $-0.44^{* \star} \pm 0.14$ & $-0.14^{*} \pm 0.05$ & $0.06^{\mathrm{ns}} \pm 0.04$ & $0.37^{* \star} \pm 0.09$ & $6.65^{* *}$ \\
\hline $\mathrm{S} 2$ & $0.17^{* \star} \pm 0.02$ & $-0.04^{* *} \pm 0.01$ & $-0.45^{* \star} \pm 0.05$ & $-0.04^{\mathrm{ns}} \pm 0.02$ & $0.08^{* *} \pm 0.02$ & $0.59^{\star \star} \pm 0.04$ & $37.50^{* *}$ \\
\hline \multicolumn{8}{|l|}{ RWC } \\
\hline $\mathrm{C}$ & $82.47^{\star \star} \pm 2.76$ & $-2.69^{* *} \pm 0.46$ & $-26.82^{\star \star} \pm 7.12$ & $-12.34^{\star *} \pm 2.66$ & $-0.32^{\mathrm{ns}} \pm 0.25$ & $16.59^{* *} \pm 4.65$ & $7.74^{* *}$ \\
\hline S1 & $79.17^{\star *} \pm 2.99$ & $-2.21^{* *} \pm 0.42$ & $-27.62^{\star \star} \pm 7.75$ & - & - & - & $2.91^{\mathrm{ns}}$ \\
\hline $\mathrm{S} 2$ & $76.2^{* \star} \pm 3.74$ & $-3.1^{* \star} \pm 0.61$ & $-32.16^{*} \pm 9.28$ & $-7.65^{\mathrm{ns}} \pm 3.64$ & $3.04^{\mathrm{ns}} \pm 2.54$ & $26.85^{* *} \pm 5.97$ & $3.45^{*}$ \\
\hline \multicolumn{8}{|l|}{ EL } \\
\hline $\mathrm{C}$ & $41.04^{* \star} \pm 7.61$ & $3.42^{* \star} \pm 1.03$ & $-20.24^{\mathrm{ns}} \pm 18.83$ & $-14.53^{\mathrm{ns}} \pm 7.54$ & $-9.25^{\mathrm{ns}_{ \pm}}+5.2$ & $3.21^{\mathrm{ns}} \pm 2.77$ & $6.46^{* *}$ \\
\hline $\mathrm{S} 1$ & $32.83^{\star \star} \pm 1.96$ & $4.69^{* \star} \pm 1.06$ & $56.05^{*} \pm 18.09$ & - & - & - & $3.98^{\mathrm{ns}}$ \\
\hline S2 & $24.29^{\star *} \pm 5.55$ & $8.93^{* \star} \pm 0.84$ & $65.87^{\star \star} \pm 14.67$ & $26.59^{\star \star} \pm 5.50$ & $-14.97^{\star \star} \pm 4.36$ & $-49.74^{* *} \pm 9.5$ & $12.72^{\star \star}$ \\
\hline \multicolumn{8}{|l|}{$\mathrm{LeaNa}^{+}$} \\
\hline \multicolumn{8}{|l|}{ C } \\
\hline $\mathrm{C}$ & $4.08^{* *} \pm 1.18$ & $2.84^{* \star} \pm 0.23$ & $2.62^{\mathrm{ns}} \pm 2.25$ & $3.14^{\star *} \pm 1.14$ & $-3.90^{* *} \pm 1.08$ & $-1.50^{\mathrm{ns}} \pm 1.19$ & $12.99^{* *}$ \\
\hline S1 & $3.56^{* \star} \pm 0.23$ & $3.47^{* \star} \pm 0.32$ & $12.76^{*} \pm 4.96$ & $7.51^{* \star} \pm 1.73$ & $-4.26^{*} \pm 1.62$ & $-8.73^{*} \pm 3.33$ & $12.21^{* *}$ \\
\hline $\mathrm{S} 2$ & $1.76^{* \star} \pm 0.77$ & $5.16^{\star \star} \pm 0.30$ & $15.98^{*} \pm 6.07$ & $7.11^{* \star} \pm 2.17$ & $-4.01^{\mathrm{ns}} \pm 1.95$ & $-12.84^{* \star} \pm 3.99$ & $9.52^{* *}$ \\
\hline \multicolumn{8}{|l|}{$\mathrm{LeaK}^{+} \mathrm{C}$} \\
\hline $\mathrm{C}$ & $77.48^{* \star} \pm 5.40$ & $-13.27^{\star \star} \pm 1.52$ & - & $-35.66^{\star \star} \pm 5.17$ & $22.88^{* \star} \pm 4.90$ & $71.07^{\star \star} \pm 9.78$ & $19.16^{* *}$ \\
\hline & & & $109.89^{\star *} \pm 14.19$ & & & & \\
\hline S1 & $70.6^{* \pm} \pm 5.41$ & $-7.63^{\star *} \pm 1.12$ & $-95.87^{* *} \pm 14.62$ & $-35.69^{\star \star} \pm 5.38$ & $14.05^{\star *} \pm 4.98$ & $56.77^{\star \star} \pm 9.73$ & $14.93^{* *}$ \\
\hline $\mathrm{S} 2$ & $41.75^{\star *} \pm 6.56$ & $-6.44^{\star *} \pm 0.97$ & $-39.5^{\mathrm{ns}} \pm 15.94$ & - & - & - & $2.20^{\mathrm{ns}}$ \\
\hline \multicolumn{8}{|l|}{$\mathrm{K}^{+} / \mathrm{Na}^{+}$} \\
\hline $\mathrm{C}$ & & & & & & & \\
\hline $\mathrm{C}$ & $18.52^{\star \star} \pm 1.8$ & $-5.13^{\star *} \pm 0.55$ & $-29.97^{\star \star} \pm 4.53$ & $-10.73^{\star *} \pm 1.67$ & $7.91^{* *} \pm 1.57$ & $18.85^{\star *} \pm 3.17$ & $17.43^{\star *}$ \\
\hline S1 & $15.11^{* *} \pm 1.08$ & $-2.69^{* *} \pm 0.28$ & $-25.49^{* \star} \pm 2.67$ & $-10.18^{* *} \pm 1.07$ & $4.34^{\star \star} \pm 0.89$ & $16.12^{* *} \pm 1.75$ & $25.85^{* *}$ \\
\hline $\mathrm{S} 2$ & $6.37^{\star \star} \pm 1.06$ & $-2.15^{\star *} \pm 0.18$ & $-10.49^{\star \star} \pm 2.54$ & $-3.01^{*} \pm 1.03$ & $2.85^{* \star} \pm 0.70$ & $7.79^{\star *} \pm 1.61$ & $11.33^{* *}$ \\
\hline
\end{tabular}


Table 3 (Continued)

\begin{tabular}{|c|c|c|c|c|c|c|c|}
\hline Traits & $\mathrm{m}$ & [d] & [h] & [i] & [j] & [1] & Wald-F \\
\hline \multicolumn{8}{|l|}{ CAT } \\
\hline $\mathrm{C}$ & $11.06^{* *} \pm 2.05$ & $-1.37^{* \star} \pm 0.22$ & $-10.25^{\mathrm{ns}} \pm 5.89$ & $-4.07^{\mathrm{ns}} \pm 2.04$ & $4.31^{*} \pm 1.91$ & $7.13^{\mathrm{ns}} \pm 3.91$ & $3.98^{*}$ \\
\hline S1 & $8.25^{* \star} \pm 1.96$ & $-3.59^{* *} \pm 0.48$ & $0.90^{\mathrm{ns}} \pm 0.49$ & - & - & - & $1.71^{\mathrm{ns}}$ \\
\hline $\mathrm{S} 2$ & $10.67^{\star \star} \pm 2.41$ & $-4.68^{* *} \pm 0.36$ & $-10.07^{\mathrm{ns}} \pm 6.58$ & $1.53^{\mathrm{ns}} \pm 1.32$ & $7.19^{* *} \pm 2.14$ & $13.06^{* \star} \pm 4.37$ & $34.30^{* *}$ \\
\hline \multicolumn{8}{|l|}{ POX } \\
\hline $\mathrm{C}$ & $26.27^{\star \star} \pm 3.38$ & $-4.85^{* *} \pm 0.54$ & $25.25^{*} \pm 8.59$ & $8.27^{\mathrm{ns}} \pm 3.32$ & $15.06^{* \star} \pm 2.59$ & $-18.01^{*} \pm 15.51$ & $16.35^{* *}$ \\
\hline S1 & $39.21^{\star \star} \pm 4.30$ & $-5.29^{* \star} \pm 0.62$ & $-11.69^{\mathrm{ns}} \pm 10.1$ & $0.12^{\mathrm{ns}} \pm 0.27$ & $17.99^{\star \star} \pm 3.85$ & $13.69^{\mathrm{ns}} \pm 8.05$ & $13.36^{* *}$ \\
\hline $\mathrm{S} 2$ & $63.58^{\star \star} \pm 5.50$ & $-6.51^{* \star} \pm 0.86$ & $-61.97^{* *} \pm 13.21$ & $-20.19^{* \star} \pm 5.37$ & $3.69^{\mathrm{ns}} \pm 3.63$ & $46.69^{* \star} \pm 8.26$ & $15.55^{* *}$ \\
\hline \multicolumn{8}{|l|}{ MDA } \\
\hline $\mathrm{C}$ & $0.66^{* *} \pm 0.04$ & $-0.06^{\star *} \pm 0.009$ & $-0.23^{\mathrm{ns}} \pm 0.12$ & - & - & - & $2.75^{\mathrm{ns}}$ \\
\hline S1 & $0.79^{* *} \pm 0.05$ & $-0.01^{\mathrm{ns}} \pm 0.007$ & $-0.58^{* \star} \pm 0.12$ & $-0.15^{* \star} \pm 0.05$ & $-0.11^{* \star} \pm 0.03$ & $0.36^{* *} \pm 0.07$ & $12.05^{* *}$ \\
\hline S2 & $0.51^{* *} \pm 0.05$ & $-0.02^{* *} \pm 0.007$ & $0.22^{\mathrm{ns}} \pm 0.13$ & $0.15^{\star \star} \pm 0.05$ & $0.01^{\mathrm{ns}} \pm 0.04$ & $-0.09^{\mathrm{ns}} \pm 0.08$ & $6.27^{\star}$ \\
\hline \multicolumn{8}{|l|}{ Proline } \\
\hline $\mathrm{C}$ & $2.32^{*} \pm 0.58$ & $-0.67^{\star \star} \pm 0.10$ & $1.21^{\mathrm{ns}} \pm 1.05$ & - & - & - & $0.77^{\mathrm{ns}}$ \\
\hline S1 & $5.11^{* *} \pm 0.58$ & $-0.77^{\star \star} \pm 0.09$ & $-4.18^{*} \pm 1.52$ & $-1.99^{*} \pm 0.57$ & $0.61^{\mathrm{ns}} \pm 0.46$ & $2.80^{*} \pm 0.99$ & $4.22^{*}$ \\
\hline $\mathrm{S} 2$ & $5.63^{* *} \pm 0.62$ & $-0.57^{\star \star} \pm 0.1$ & $-4.93^{*} \pm 1.56$ & $-2.05^{*} \pm 0.62$ & $-0.15^{\mathrm{ns}} \pm 0.14$ & $3.29^{* *} \pm 0.99$ & $3.99^{*}$ \\
\hline
\end{tabular}


Table 4 Estimates of variance components using restricted maximum likelihood for mixed linear model

\begin{tabular}{|c|c|c|c|c|c|c|c|c|}
\hline Trait & Salinity rate & $\overline{\sigma_{A}^{2}}$ & $\overline{\sigma_{\mathrm{D}}^{2}}$ & $\sigma_{\mathrm{AD}}$ & $\overline{\sigma_{\mathrm{E}}^{2}}$ & $\mathrm{~h}^{2}{ }_{\mathrm{bs}}$ & $\mathrm{h}^{2} \mathrm{~ns}$ & $\overline{\mathrm{a}}$ \\
\hline \multirow[t]{3}{*}{$\mathrm{GFeC}$} & $\mathrm{C}$ & 72.74 & 66.04 & 31.41 & 15.84 & 0.96 & 0.50 & 1.34 \\
\hline & S1 & 41.24 & 26.25 & 17.11 & 9.45 & 0.96 & 0.47 & 1.12 \\
\hline & S2 & 39.66 & 15.73 & 19.16 & 27.35 & 0.89 & 0.47 & 0.89 \\
\hline \multirow[t]{3}{*}{ GZnC } & $\mathrm{C}$ & 173.99 & 149.83 & 94.51 & 97.16 & 0.92 & 0.38 & 1.31 \\
\hline & S1 & 6.71 & 37.83 & 7.82 & 76.12 & 0.67 & 0.08 & 3.35 \\
\hline & S2 & 64.40 & 32.94 & 21.16 & 21.74 & 0.94 & 0.51 & 1.01 \\
\hline \multirow[t]{3}{*}{ 100-SW } & $\mathrm{C}$ & 0.13 & 0.14 & 0.03 & 0.06 & 0.93 & 0.40 & 1.47 \\
\hline & S1 & 0.01 & 0.07 & 0.02 & 0.11 & 0.73 & 0.07 & 3.74 \\
\hline & S2 & 0.05 & 0.06 & 0.03 & 0.03 & 0.93 & 0.33 & 1.54 \\
\hline \multirow[t]{3}{*}{ GY } & C & 0.15 & 0.43 & 0.07 & 0.41 & 0.83 & 0.19 & 2.39 \\
\hline & S1 & 0.21 & 0.04 & 0.11 & 0.26 & 0.82 & 0.47 & 0.61 \\
\hline & S2 & 0.08 & 0.05 & 0.01 & 0.05 & 0.90 & 0.51 & 1.11 \\
\hline \multirow[t]{3}{*}{ RL } & $\mathrm{C}$ & 0.90 & 0.63 & 0.99 & 3.52 & 0.68 & 0.24 & 1.18 \\
\hline & S1 & 1.95 & 1.57 & 0.09 & 1.34 & 0.89 & 0.48 & 1.26 \\
\hline & S2 & 3.18 & 2.03 & 0.01 & 0.83 & 0.95 & 0.58 & 1.12 \\
\hline \multirow[t]{3}{*}{ RFW } & $\mathrm{C}$ & 0.026 & 0.025 & 0.0007 & 0.018 & 0.90 & 0.40 & 1.38 \\
\hline & S1 & 0.041 & 0.024 & 0.003 & 0.012 & 0.94 & 0.56 & 1.08 \\
\hline & S2 & 0.065 & 0.024 & 0.007 & 0.007 & 0.98 & 0.66 & 0.85 \\
\hline \multirow[t]{3}{*}{ RDW } & $\mathrm{C}$ & 0.002 & 0.0005 & 0.0004 & 0.003 & 0.74 & 0.51 & 0.70 \\
\hline & S1 & 0.003 & 0.002 & 0.001 & 0.002 & 0.90 & 0.45 & 1.15 \\
\hline & S2 & 0.006 & 0.006 & 0.003 & 0.0007 & 0.98 & 0.39 & 1.41 \\
\hline \multirow[t]{3}{*}{ RWC } & $\mathrm{C}$ & 5.13 & 3.76 & 1.63 & 4.73 & 0.87 & 0.42 & 1.21 \\
\hline & S1 & 7.27 & 3.09 & 0.54 & 3.83 & 0.93 & 0.37 & 0.92 \\
\hline & S2 & 8.42 & 21.11 & 0.19 & 18.68 & 0.82 & 0.23 & 2.24 \\
\hline \multirow[t]{3}{*}{ EL } & $\mathrm{C}$ & 43.14 & 29.02 & 3.54 & 5.76 & 0.97 & 0.55 & 1.16 \\
\hline & S1 & 1.19 & 8.42 & 0.97 & 26.75 & 0.54 & 0.06 & 3.76 \\
\hline & S2 & 23.03 & 20.51 & 0.96 & 22.71 & 0.85 & 0.44 & 1.33 \\
\hline \multirow[t]{3}{*}{$\mathrm{LeaNa}^{+} \mathrm{C}$} & $\mathrm{C}$ & 1.96 & 1.64 & 0.66 & 1.01 & 0.93 & 0.42 & 1.29 \\
\hline & $\mathrm{S} 1$ & 3.09 & 2.44 & 1.82 & 1.63 & 0.93 & 0.39 & 1.25 \\
\hline & S2 & 1.11 & 0.49 & 1.60 & 2.29 & 0.80 & 0.28 & 0.93 \\
\hline \multirow[t]{3}{*}{$\mathrm{LeaK}^{+} \mathrm{C}$} & $\mathrm{C}$ & 28.75 & 18.91 & 11.40 & 34.18 & 0.84 & 0.40 & 1.14 \\
\hline & S1 & 22.34 & 20.71 & 9.91 & 25.99 & 0.86 & 0.36 & 1.36 \\
\hline & S2 & 21.03 & 12.34 & 6.80 & 15.93 & 0.88 & 0.46 & 1.08 \\
\hline
\end{tabular}


Table 4 (Continued)

\begin{tabular}{lllllllll}
\hline Trait & Salinity rate & \multicolumn{1}{c}{$\sigma_{\mathrm{A}}^{2}$} & $\sigma_{\mathrm{D}}^{2}$ & $\sigma_{\mathrm{AD}}$ & $\sigma_{\mathrm{E}}^{2}$ & $\mathrm{~h}^{2}{ }_{\mathrm{bs}}$ & $\mathrm{h}^{2}{ }_{\mathrm{ns}}$ & $\overline{\mathrm{a}}$ \\
\hline $\mathrm{LeaK}^{+} / \mathrm{Na}^{+} \mathrm{C}$ & $\mathrm{C}$ & 3.22 & 3.39 & 4.46 & 3.19 & 0.91 & 0.26 & 1.45 \\
& $\mathrm{~S} 1$ & 0.90 & 0.47 & 0.84 & 1.23 & 0.84 & 0.34 & 1.02 \\
& $\mathrm{~S} 2$ & 0.03 & 0.34 & 0.56 & 0.28 & 0.91 & 0.03 & 4.76 \\
$\mathrm{CAT}$ & $\mathrm{C}$ & 0.30 & 0.35 & 0.71 & 1.53 & 0.73 & 0.16 & 1.53 \\
& $\mathrm{~S} 1$ & 0.64 & 0.83 & 1.25 & 2.82 & 0.74 & 0.17 & 1.61 \\
& $\mathrm{~S} 2$ & 1.57 & 3.11 & 0.01 & 4.29 & 0.76 & 0.25 & 1.99 \\
POX & $\mathrm{C}$ & 5.34 & 3.07 & 0.27 & 5.13 & 0.83 & 0.51 & 1.07 \\
& $\mathrm{~S} 1$ & 5.08 & 10.46 & 0.41 & 15.21 & 0.76 & 0.24 & 2.03 \\
& $\mathrm{~S} 2$ & 21.16 & 9.86 & 0.74 & 8.48 & 0.92 & 0.61 & 0.96 \\
MDA & $\mathrm{C}$ & 0.0001 & 0.0005 & 0.0001 & 0.0014 & 0.63 & 0.09 & 3.16 \\
& $\mathrm{~S} 1$ & 0.003 & 0.0008 & 0.0003 & 0.0008 & 0.95 & 0.69 & 0.73 \\
& $\mathrm{~S} 2$ & 0.004 & 0.002 & 0.0003 & 0.0014 & 0.94 & 0.60 & 1.00 \\
& $\mathrm{C}$ & 0.22 & 0.21 & 0.04 & 0.28 & 0.84 & 0.39 & 1.38 \\
& $\mathrm{~S} 1$ & 0.06 & 0.05 & 0.06 & 0.13 & 0.81 & 0.28 & 1.29 \\
& $\mathrm{~S} 2$ & 0.09 & 0.01 & 0.03 & 0.11 & 0.62 & 0.56 & 0.47 \\
\hline
\end{tabular}

